\title{
IDENTIFIKASI BAKTERI AEROB PADA URIN PORSI TENGAH PASIEN PENYAKIT GINJAL KRONIK STADIUM 5 DI BLU RSUP PROF. R.D. KANDOU MANADO
}

\author{
${ }^{1}$ Nur Dinah Mamonto \\ ${ }^{2}$ Standy Soeliongan \\ ${ }^{2}$ Heriyannis Homenta
}

\author{
${ }^{1}$ Kandidat Skripsi Fakultas Kedokteran Universitas Sam Ratulangi \\ ${ }^{2}$ Bagian Mikrobiologi Fakultas Kedokteran Universitas Sam Ratulangi \\ Email:damamonto_11196@yahoo.com
}

\begin{abstract}
Chronic kidney disease (CKD) is a chronic disease that can lead to some abnormality in the body's defense system which allows an increased risk of infection, one urinary tract infection. In patients with CKD stage 5, impaired immunological function and infections often occur. A high incidence of infection found in uremic patients. Uremia suppress the function of most of the patient's immune cells, causing immunological complications of CKD patients more susceptible to infection than normal people. The purpose of this study is to identify the type of aerobic bacteria in the urine of patients with CKD Stage 5 in Inpatient B and C BLU Inpatient Hospital. PROF. R.D Kandou Manado. This study used a prospective descriptive method with a sample of 20 samples and carried out in November 2014 - January 2015. The results of urine culture and biochemical tests showed bacterial growth were identified, namely Escherichia coli, Streptococcus sp., Staphylococcus sp., Coccus Gram-negative, Gram Coccus positive, Seratia Marcesnes, and Bacillus subtilis. From the results of this study, the conclusions on most types of bacteria found were Bacillus subtilis (50\%).
\end{abstract}

Keywords: CKD stage 5, aerobic bacteria, urine middle portion

\begin{abstract}
Abstrak: Penyakit ginjal kronis (PGK) merupakan penyakit kronis yang dapat menyebabkan beberapa kelainan di dalam sistem pertahanan tubuh yang memungkinkan peningkatan risiko terkena infeksi, salah satunya infeksi saluran kemih. Pada penderita PGK stadium 5, fungsi imunologis terganggu dan infeksi sering terjadi. Kejadian infeksi yang tinggi dijumpai pada penderita uremik. Uremia menekan fungsi sebagian besar sel imun penderita, adanya komplikasi imunologis menyebabkan penderita PGK lebih mudah terkena infeksi dibandingkan orang normal. Tujuan dari penelitian ini adalah untuk mengidentifikasi jenis bakteri aerob pada pemeriksaan urin pasien PGK Stadium 5 di Instalasi Rawat Inap B dan Instalasi Rawat Inap C BLU RSUP. PROF. R.D Kandou Manado. Penelitian ini menggunakan metode deskriptif prospektif dengan sampel sebanyak 20 sampel dan dilaksanakan pada bulan November 2014 - Janurari 2015. Hasil kultur urine dan uji biokimia menujukkan pertumbuhan bakteri yang teridentifikasi yaitu Eschericia coli, Streptococcus sp., Staphylococcus sp., Coccus Gram negatif, Coccus Gram positif, Seratia Marcesnes, dan Bacillus Subtilis. Dari hasil kesimpulan pada penelitian ini didapatkan jenis bakteri yang paling banyak di temukan adalah Bacillus Subtilis (50\%).
\end{abstract}

Kata Kunci : PGK stadium 5, bakteri aerob, Uuin porsi tengah 
Penyakit ginjal kronik (PGK) merupakan kerusakan ginjal atau penurunan kemampuan filtrasi glomerulus (Glomerular Filtration Rate/GFR) kurang dari $60 \mathrm{~mL} / \mathrm{min} / 1.73 \mathrm{~m}^{2}$ selama tiga bulan atau lebih yang irreversibel dan didasari oleh banyak faktor. ${ }^{1}$ Diagnosis PGK ditegakkan berdasarkan Tes Klirens Kreatini (TKK) sama atau kurang dari 25 $\mathrm{ml} /$ menit. PGK merupakan perkembangan gagal ginjal yang progresif dan lambat, biasanya berlangsung beberapa tahun dan memiliki beberapa tahapan seperti ringan, sedang, atau berat. Gangguan ginjal yang telah berada pada tahap berat ditunjukkan dengan ketidakmampuan ginjal membuang sisa-sisa zat metabolisme dari dalam tubuh. Hal ini menyebabkan tubuh dipenuhi dengan cairan dan racun sehingga timbul gejala seperti mual, muntah dan sesak napas yang memerlukan hemodialisis darah sesegera mungkin. ${ }^{2}$

Hemodialisis merupakan salah satu terapi pengganti ginjal yang paling banyak dipilih oleh para penderita gagal ginjal terminal. Pada prinsipnya terapi hemodialisis adalah untuk menggantikan kerja dari ginjal yaitu menyaring dan membuang sisa-sisa metabolisme dan kelebihan cairan, membantu menyeimbangkan unsur kimiawi dalam tubuh serta bantu menjaga tekanan darah. Keadaan gagal ginjal kronik yang memerlukan hemodialisis adalah faal ginjal yang masih tersisa sudah minimal seperti tidak bisa diberi pengobatan konservatif dan farmakologik., ${ }^{1,3}$

PGK merupakan masalah medik, sosial dan ekonomi terutama di negara-negara berkembang yang memiliki keterbatasan untuk membiayai perawatan. Prevalensi dan insidensi gagal ginjal terus meningkat di dunia termasuk di Amerika Serikat. Data dari United State Renal Data System (USRDS) mengindikasikan bahwa gagal ginjal kronik meningkat 104\% antara tahun 1990-2001. Di malaysia, dengan populasi 18 juta, diperkirakan terdapat 1800 kasus baru gagal ginjal kronik pertahunnya. Dinegara-negara berkembang lainnya, insiden ini diperkirakan sekitar 40-60 kasus perjuta penduduk per tahun. ${ }^{4-5}$

Akibat dari penyakit yang menahun ini menimbulkan gejala klinis yang merugikan pada keseluruhan sistem tubuh yang lain dan di antaranya adalah terkait penurunan fungsi imunitas tubuh dan leukosit. Salah satu komplikasi PGK adalah gangguan imunologis. Pada penderita PGK, fungsi imunologis terganggu dan infeksi sering terjadi. Kejadian infeksi yang tinggi dijumpai pada penderita uremik. Uremia menekan fungsi sebagian besar sel imun penderita. Adanya komplikasi imunologis menyebabkan penderita PGK lebih mudah terkena infeksi dibandingkan orang normal. Penderita PGK mudah terkena infeksi seperti infeksi saluran kemih. ${ }^{6}$

Penelitian yang dilakukan oleh Endriani S., tentang Pola Resistensi Penyebab Infeksi Saluran Kemih memperlihatkan bahwa bakteri penyebab infeksi saluran kemih adalah 28\% Escherichia Coli, 26\% Klebsiella Sp., 18\% Pseudomonas Sp., 10\% Staphylococcus epidermidis, 8\% Staphylococcus aureus, 6\% Streptococcus Sp., 2\% Enterobacter Sp., dan $2 \%$ Proteus Sp. ${ }^{7}$

Berdasarkan latar belakang diatas, maka peneliti tertarik untuk mengidentifikasi bakteri aerob pada urine pasien penykit ginjal kronik stadium 5

\section{METODE PENELITIAN}

Penelitian yang dilakukan bersifat deskriptif prospektif. Penelitian ini dilakukan pada bulan november 2014 Januari 2015. Terdapat 20 sampel dalam penelitian ini dengan diagnosis Penyakit Ginjal Kronik Stadium 5. Pengolaan sampel dilakukan di Laboratorium Mikrobiologi Fakultas kedokteran Univeristas Sam Ratulangi dengan teknik kultur urin dan dilanjutkan dengan uji biokimia.

\section{HASIL PENELITIAN}

Penelitian ini di lakukan di Laboratorium Mikrobiologi Fakultas Kedokteran Universitas Sam Ratulangi 
Manado terhadap 20 sampel urin pasien PGK stadium 5.

Berdasarkan Gambar 1 distrubusi sampel menurut jenis kelamin, dari 20 sampel dari 20 sampel yang didapatkan, jenis kelami laki-laki berjumlah 13 orang (65\%) dan perempuan 7 orang (35\%) yang melakukan rawat inap di BLU RSUP Prof. Dr. R. D Kandou Manado.

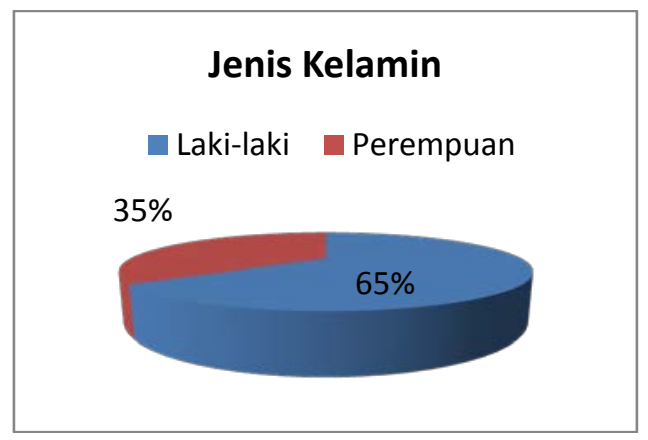

Gambar 1. Distrubusi sampel menurut jenis kelamin

Tabel 1. Distrubusi sampel menurut kelompok umur

\begin{tabular}{ccc}
\hline $\begin{array}{c}\text { Kelompok } \\
\text { umur }\end{array}$ & $\begin{array}{c}\text { Frekuensi } \\
(\mathrm{N})\end{array}$ & $\begin{array}{c}\text { Presetntase } \\
\%\end{array}$ \\
\hline $21-30$ & 2 & 10,0 \\
$31-40$ & 1 & 5,0 \\
$41-50$ & 2 & 10,0 \\
$51-60$ & 4 & 20,0 \\
$61-70$ & 9 & 45,0 \\
& 2 & 10,0 \\
\hline Total & 20 & 100,0 \\
\hline
\end{tabular}

Berdasarkan tabel 1 distrubusi sampel menurut kelompok umur pasien yang diteliti, didapati bahwa 20 pasien PGK yang di rawat di Instalasi Rawat Inap B dan Instalasi Rawat Inap C yaitu 21 - 30 tahun (10\%), 31 - 40 tahun (5\%), 41 - 50 tahun (10\%), 51 - 60 tahun (20\%), 61 - 70 tahun (45\%), >70 tahun (10\%). Presentasi terbanyak pada kelompok umur 61 - 70 tahun (45\%).

Gambar 2 memperlihatkan setelah dilakukan pewarnaan gram maka diperoleh Gram positif sebanyak 17 sampel (85\%) dan Gram negatif sebanyak 3 sampel (15\%).

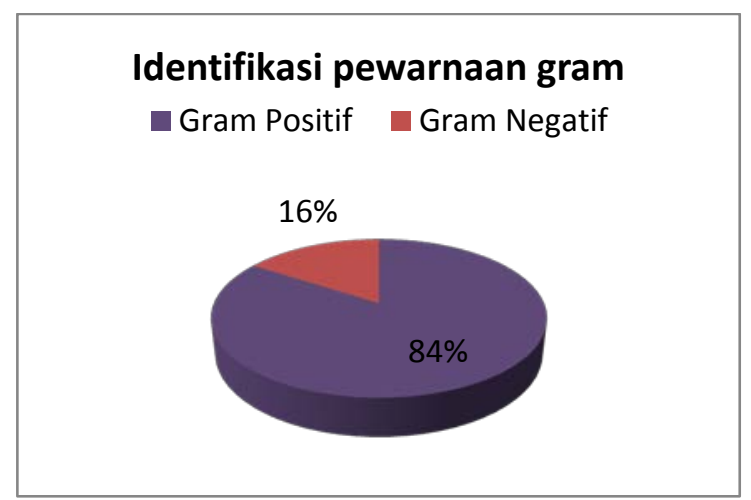

Gambar 2. Distrubusi Sampel berdasarkan pertumbuhan bakteriuria dalam urin

Tabel 2. Distrubusi Sampel berdasarkan jenis bakteri pada pasien PGK stadium 5 yang melakukan terapi Hemodialisis

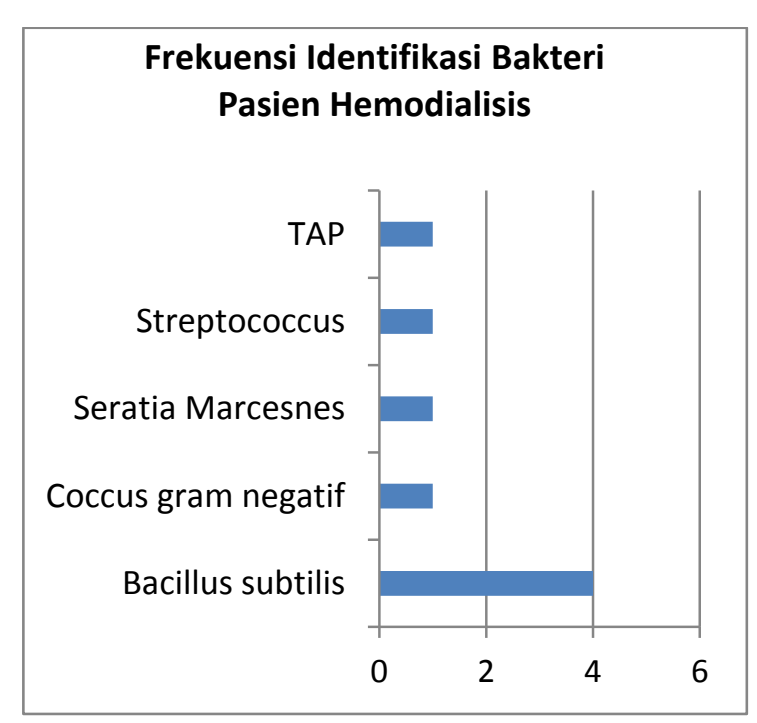

Pada Tabel 2 dapat dilihat dari 8 sampel hasil kultur urin, yang menunjukkan adanya pertumbuhan bakteri ditemukan 4 jenis bakteri. Yang terbanyak adalah Bacillus Subtilis sebanyak 4 sampel (50\%), kemudian Coccus Gram negatif 
(12,5\%), Seratia Marcesnes (12,5\%), Streptococcus (12,5\%), dan 1 sampel tidak didapatkan pertumbuhan bakteri (TAP).

Tabel 3. Distrubusi Sampel berdasarkan jenis bakteri pada pasien PGK stadium 5 yang melakukan terapi non - Hemodialisis

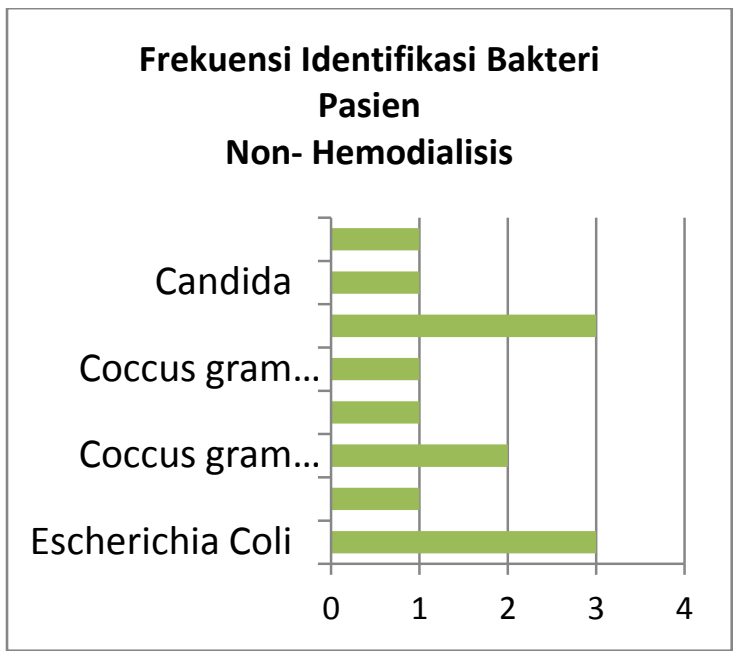

Pada Tabel 3 dapat dilihat dari 8 sampel hasil kultur urin, yang menunjukkan adanya pertumbuhan bakteri ditemukan 6 jenis bakteri dan 1 jenis fungi. Yang terbanyak adalah Escherichia coli 3 sampel (25\%), kemudian Coccus Gram negatif (16,6\%), Coccus Gram positif (8,3\%), Streptococcus (8,3\%), Staphylococcus (8,3\%), Bacillus Subtilis (8,3\%). 1 jenis candida, dan 3 sampel tidak didapatkan pertumbuhan bakteri (TAP).

\section{BAHASAN}

Berdasarkan penelitian yang dilakukan terhadap pasien PGK stadium 5 yang dirawat diInstalasi Rawat Inap $\mathrm{B}$ dan Instalasi Rawat Inap C RSUP. Prof. Dr. R. D Kandou Manado periode November Desember 2014, dimana jumlah sampel yang memenuhi kriteria sebanyak 20 sampel dimana 12 sampel adalah pasien PGK yang diterapi dengan hemodialisis dan 8 sampel pasien yang tidak diterapi dengan hemodialisis atau pasien PGK nonhemodialisis. Pemeriksaan sampel dilakukan di Laboratorium Mikrobiologi Fakultas Kedokteran Universitas Sam Ratulangi Manado.

Berdasarkan distribusi menurut jenis kelamin, pada penelitian ini didapatkan 13 sampel berjenis kelamin laki-laki dan 7 sampel berjenis kelamin perempuan. Hal ini disebabkan karena, pada saat pengambilan sampel, pasien yang dirawat diInstalasi Rawat Inap B dan Instalasi Rawat Inap $\mathrm{C}$ paling banyak berjenis kelamin laki-laki, dan juga pada saat pengambilan sampel yang paling banyak bersedia diambil sampel urinnya adalah pasien berjenis kelamin laki-laki.

Pada penelitian ini terdapat 20 pasien dengan umur berkisar antara 21 - 74 tahun. Hasil penelitian didapatkan kejadian terendah pada pasien kelompok umur 31 40 tahun (5\%), dan angka kejadian tertinggi pada pasien kelompok umur 61 - 70 tahun (45\%). Hasil ini sesuai dengan penelitian sebelumnya oleh DH Fritiwi yang menyebutkan bahwa faktor risiko terbanyak pada pasien yang berumur lebih dari 50 tahun. Hal ini disebabkan karena dengan bertambahnya usia, terdapat pola daya tahan tubuh dan perubahan anatomi maupun fisiologis organ tubuh, juga didukung dengan faktor risiko dan riwayat penyakit metabolik yang pada umumya diderita seseorang pada usia lanjut.

Berdasarkan hasil kultur urin, terdapat 7 jenis bakteri yang teridentifikasi, yaitu Eschericia coli, Streptococcus sp., Staphylococcus sp., Coccus Gram negatif, Coccus Gram positif, Seratia Marcesnes, dan Bacillus Subtilis. Dalam penelitian yang dilakukan Mahfouz dkk di Arab Saudi, jenis bakteri yang ditemukan adalah Eschericia Coli, Klebsiella sp, Enterobacter cloacae, Streptococcu sps., Seratia sp, Staphylococcus aureus dan Gram negatif Bacili yang lain.

Pada penelitian ini, dari 20 pasien terdapat 8 pasien yang menjalani terapi hemodialisis. Bacillus subtilis (50\%) merupakan jenis bakteri terbanyak yang ditemukan pada 8 sampel urin pasien yang melakukan terapi hemodialisis. Kemudian ditemukan bakteri lain seperti Cocus Gram negatif (12,5\%), Seratia Marscesnes (12,5\%) dan Streptococcus sp. (12,5\%). Dari hasil yang diperoleh, terdapat beberapa jenis bakteri yang mirip dengan 
jenis bakteri yang ditemukan dari penelitian Mahfouz, dkk di atas yaitu, Seratia Marscesnes dan Streptococcus sp.

Pada 12 sampel yang tidak melakukan terapi hemodialisis, Eschericia Coli (25\%) merupakan bakteri terbanyak yang ditemukan. Dalam literatur, bakteri jenis E.Coli merupakan jenis bakteri yang paling banyak ditemukan dalam urin. Hal ini juga diperkuat oleh penelitian yang dilakukan oleh Clara Shalvi S menyebutkan bahwa bakteri E. Coli (45\%) adalah bakteri terbanyak yang ditemukan. Sifat E. Coii unik karena dapat menyebabkan infeksi primer pada usus misalnya diare pada anak, dan juga mampu menimbulkan infeksi jaringan tubuh lain di luar usus seperti infeksi saluran kemih. Bakteri lain yang ditemukan yaitu, Streptococcus sp. (8,3\%), Staphylococcus sp. (8,3\%), Coccus Gram negatif (16,6\%), Coccus Gram positif (8,3\%), dan Bacillus Subtilis (8,3\%).

\section{SIMPULAN}

1. Terdapat 7 jenis bakteri yang berhasil diidentifikasi, yaitu Eschericia colii, Streptococcus, Staphylococcus, Cocus gram negatif, Coccus Gram positif, Seratia Marcesnes, dan Bacillus Subtilis.

2. Jenis bakteri yang paling banyak ditemukan pada pasien PGK yang menjalani terapi hemodialisis adalah bakteri Bacillus Subtili (50\%)

3. Jenis bakteri yang paling banyak ditemukan pada pasien PGK yang tidak menjalani terapi hemodialisis adalah Eschericia coli (25\%)

\section{DAFTAR PUSTAKA}

1. Muharni S I. Pola hidup penderita gagal ginjal kronik sebelum menjalani terapi hemodialisa di Rumah Sakit Umum Daerah Kota Langsa tahun 2009. Skripsi. Fakultas Keperawatan USU. 2009

2. Hafid M. Insiden infeksi saluran kemih (ISK) pada penderita gagal ginjal kronik (GGK). Skripsi. Fakultas Kedokteran Universitas Sumatera Utara, Medan,2011

3. Silvani D. Hubungan periode lama hemodialisis dengan status albumin penderita gagal ginjal kronik di unit hemodialisis RSUD. Prof. Dr. Margono Sukarjo Purwokerto. Mandala of health. Volume 5. September, 2010

4. Kato S., Chmielewski M., Honda H., Pecoits-Filho R, Matsuo S., Yuzawa Y., Tranaeus A., Stenvinkel P., Lindholm B., 2008. Aspects of Immune Dysfunction in End-stage Renal Disease.American Society of Nephrology

5. Suwitra K. Penyakit ginjal kronik. Dalam, Buku Ajar Ilmu penyakit dalam.Ed. V.Edit, Sudoyo A., Sutyohadi B., Alwi I., Simadribata K., Setiati S. Jakarta : InternaPublishing; 2010. 1036

6. Hapsari AP. Perbedaan leukosituri antara penderita penyakit ginjal kronik stadium 5 dengan diabetes melitus dan tanpa diabetes melitus. Skripsi. Fakultas Kedokteran Universitas Diponegoro, Semarang,2012

7. Joey. Distribusi Bakteri Aerob Penyebab Infeksi Saluran Kemih pada Pasien Rawat Jalan dan Rawat Inap di RSUP H. Adam Malik Medan Periode Januari 2013 - Juni 2013. Fakultas Kedokteran Universitas Sumatera Utara, Medan, 2012. 